\title{
Mechanical and flexural performance of self compacting concrete with natural fiber
}

Sethuraman Muthusamy Kavitha (Main and Corresponding Author)

Department of Civil Engineering, Alagappa Chettiar Government College of Engineering \& Technology

Karaikudi 630003, Tamil Nadu(India)

smkaccet@gmail.com

Venkatesan G.

Department of Civil Engineering

University College of Engineering Tiruchirapalli (BIT campus), Anna University

Tiruchirapalli-620024 (India)

gvenkat1972@gmail.com

\section{Siva Avudaiappan}

Departamento de Ingeniería en Obras Civiles, Universidad de Santiago de Chile

Ave. Ecuador 3659, Estación Central, Santiago (Chile)

shiva86aaa@gmail.com

\section{Erick I. Saavedra Flores}

Departamento de Ingeniería en Obras Civiles, Universidad de Santiago de Chile

Ave. Ecuador 3659, Estación Central, Santiago (Chile)

erick.saavedra@usach.cl

\author{
ManuscriptCode:13964 \\ Date of Acceptance/Reception:25.07.2020/08.12.2019 \\ DOI:10.7764/RDLC.19.2.370
}

\begin{abstract}
This paper investigates the effect of sisal fiber addition on fresh ,mechanical properties of self compacting concrete(SCC) and flexural performance of fiber reinforced RC beams made with mineral admixtures like Meta Kaolin (MK) and Fly Ash (FA)which is an industrial waste. The mixes were prepared by varying MK content from $5 \%$ to $15 \%$ with $5 \%$ increment with constant fly ash content of $30 \%$. The results reveal that increasing the content of MK beyond $10 \%$ leads to reduction in strength. And also the negative influence of MK and fiber addition on workability performance was overcome by the addition of FA, super plasticizer and viscosity modifying agent (VMA). Based on the test results it is evidenced that FA and MK make use of mineral admixture in the production of SCC. It also clarifies that the addition of sisal fiber improves mechanical properties of concrete. The research work shows that the ultimate load of fiber reinforced RC beams was raised when compared to normal RC beams. The flexural toughness and ductility of concrete was found to increase appreciably when sisal fiber was added.
\end{abstract}

Keywords: Ductility, Fly ash, Meta Kaolin, Self-compacting concrete, Sisal fiber.

Self-compacting concrete is a new kind of high performance concrete which flows easily and becomes consolidated under its self weight without segregation and bleeding. SCC which was developed in the late 1980s, mainly used for highly congested reinforced concrete structures. Nowadays, many countries are extensively using this concrete for various Civil Engineering applications since SCC enhances the lastingness of structures, provides better surface finish and safer working environment by annihilating the vibration noise (Okamura, Ozawa,\&Ouchi, 2000; Domone, 2007; Siddique, 2011). When compared with conventional concrete, SCC has low water to binder ratio and coarse aggregate content. In order to enhance the flowability of SCC, a large quantity of powder content like fly ash, GGBS, lime powder, MK etc., needs to be added(Khatib, 2008). By minimizing the usage of cement content in making of SCC, we can save our environment from green house effect since in the production of cement $87 \%$ of $\mathrm{CO}_{2}$ is emitted, further by reducing cement we preserve from high desolation of natural resources like $\mathrm{CaCO}_{3}$ etc. Therefore there is a need to economize the use of cement with supplementary cementitious materials (Uysal, 2019; Shetty, 2008).

Pozzolanic admixtures like fly ash, silica fume, rice husk ash, slag and MK can be used as supplementary cementitious ingredients in the composition of high strength concrete which will have enhanced workability, strength and durability. Fly ash is a waste material generated in thermal power plants, when powdered coal is used as fuel. The dumping of FA creates a nuisance to the atmosphere but also reduces the utility of land. The addition of FA enhances the workability of SCC and it takes an advantage in scaling down the cracking potential of concrete as heat released during hydration 
of cement is reduced. Thus the addition of FA as pozzolanic admixture not only enhances the properties of concrete and also curbs green house effect. The use of fly ash as concrete admixture not only extends technical advantages to the properties of the concrete but also contributes to the environmental pollution control (Uysal, 2011). It is evidenced from the research work carried out by (Siddique, 2011), the addition of FA upto 30\% as cementitious material improves fresh properties of SCC. Chemical admixture is essential to enhance the flowability as well as resistance to segregation in SCC. The dosage of superplasticizer needed to achieve self compactability can be reduced by the addition of FA (Khatib, 2008). The addition of FA not only enhances the flowabiliy of concrete but due to delayed pozzolanic action, improves the long term strength (Oyejobi, 2019). Increased workability and long term strength is achieved by the addition of fly ash.

Some researchers have found that Silica fume can be used as mineral admixture in making SCC. Some researchers have been established that MK can be used as partial replacement for cement and also found that MK enhances the strength of concrete(Jin\&Li, 2003). MK is highly reactive pozzolana and manufactured by calcining pure or refined clay at a temperature of $650^{\circ} \mathrm{C}-850^{\circ} \mathrm{C}$ and it is pulverized to attain a fineness of $700-900 \mathrm{~m}^{2} / \mathrm{kg}$ (Santha Kumar, 2006). The extent of pores in cement paste is minimized by the addition of $\mathrm{MK}$ and also it separates the finer particle and hence the permeability of concrete is reduced considerably (Khatib, 2008). A Plain Concrete intrinsically possesses a number of tiny cracks and it enhances the brittleness of concrete. So that the concrete is weak in tensile strength, ductileness and offer mere resistance against cracking. Some researchers have found that the cracking mechanism of concrete will be changed from a brittle to a ductile behavior by the addition of fiber. Some authors have found that sisal fibers reduce shrinkage, crack in composites. Natural fibers are easily gathered from inexhaustible reserves at low cost. The production of sisal fiber as compared with synthetic fibers or even with asbestos fibers needs much less energy in addition to the ecological, social and economical benefits. Among all the natural fibers, sisal fiber can be used as reinforcing material due to its high strength and stiffness (Zhao,Li \& Bai, 2014; Zhang, Alam, Sun, Su, \&Samali, 2018). The addition of sisal fiber in concrete improves compressive strength and flexural strength (Bao\& Li, 2010). During the past two decades sisal fiber has been used as reinforcing material in cement and polymer based composite (Silva, Chawla \& Filho,2008). However a limited number of standard research works have been carried out at international level to evaluate the performance of sisal fiber in SCC as reinforcement.

In this experimental work, the effect of fibers on workability of concrete is overcome by adopting SCC (Köroğlu, 2019) and an appropriate mix has been arrived with typical features of SCC, as per EFNARC guidelines. Since the addition of FA enhances the flowability of concrete and also the addition of MK increases, the long term strength, these two admixtures were added in to the SCC. In this study, the optimum dose of replacement of MK was determined while FA was kept as constant at $30 \%$. Then sisal fiber was added in to SCC containing FA and MK and the effective replacement of sisal fiber in cement was determined. The effective replacement of MK and sisal fiber was based on workability performance and mechanical properties. Workability tests like slump flow, J-ring, V-funnel, L-box and U-box were carried out to check the required characteristics of SCC and also tests to determine the mechanical properties such as compressive strength and split tensile strength were conducted. Then the flexural performance of sisal fiber reinforced $\mathrm{RC}$ beams was evaluated from displacement, flexural toughness and ductility index.

Methodology

Ordinary Portland cement (OPC-53 Grade) having a specific gravity of 3.14 confirmed to Indian standard specification (BIS:12269, 2013) was used. Fly ash Class F gathered from Mettur Thermal Power Station, Mettur, India with a specific gravity of 2.16 was used. Meta Kaolin purchased from M/s JeetmullJaichandlal (M) Pvt Itd, Chennai, India with a specific gravity of 2.6 was used. Locally available natural sand with a maximum size of $2.36 \mathrm{~mm}$ with a specific gravity of 2.58 falls in zone II was used as fine aggregate. Crushed granite stone of passing $12.5 \mathrm{~mm}$ and retained on $10 \mathrm{~mm}$ with a specific gravity of 2.74 was added as coarse aggregate. Both fine and coarse aggregates conformed to Indian standard Specification (BIS: 383,2016). Ordinary potable water was used. Poly carboxylic ether based super plasticizer complying with, (BIS: 9103,1999) was used as water reducing admixture. Sisal fiber is a natural fiber of Agavaceae (Agave) family that yields a stiff fiber and they are straight, smooth and yellow in colour. Sisal fiber purchased from local source (Coimbatore, Tamil Nadu, India) shown in Figure 1 was used as reinforcing material to prevent brittle failure in concrete and they were distributed randomly in SCC. The properties of sisal fiber was presented in Table1. 


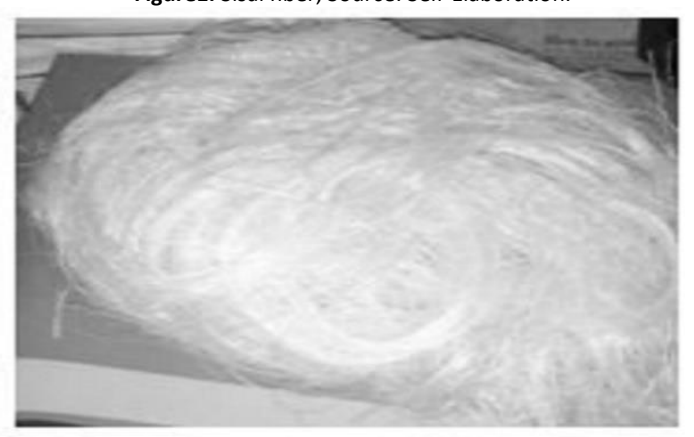

Table 1. Properties of Sisal fiber. Source: Venkateshwaran, Elayaperumal, Alavudeen, \&Thiruchitrambalam(2011).

\begin{tabular}{ll}
\hline Cellulose \% & 65 \\
Hemicelluloses \% & 12 \\
Lignin \% & 9.9 \\
Density $\left(\mathrm{kg} / \mathrm{m}^{3}\right)$ & 1450 \\
Flexural modulus $(\mathrm{GPa})$ & $12.5-17.5$ \\
Young's modulus $(\mathrm{GPa})$ & 3.774 \\
Tensile strength $(\mathrm{MPa})$ & 68 \\
Length $\mathrm{mm}$ & 50 \\
Diameter $\mu \mathrm{m}$ & $200-300$ \\
\hline
\end{tabular}

\section{Micro structural study}

The greater strength at later age of hardened concrete admixed with FA and MK is due to continued pozzolanic reactivity. From EDAX (Energy Dispersive Analysis of X Rays) results shown in Figure 2a, concrete admixed with FA and MK has nearly $50 \%$ of silica content thus definitely improves filling effect in SCC. Around $15 \%$ of aluminous compound in concrete ensures some pozzolanic reaction in concrete which may contribute to the compressive strength. The sum of ferric oxide, alumina and silica must be at least $70 \%$ in FA for possible use in concrete (Karmegam, 2014). The sum of these oxides in FA as well as MK, promises that it may be useful to increase the strength of SCC.
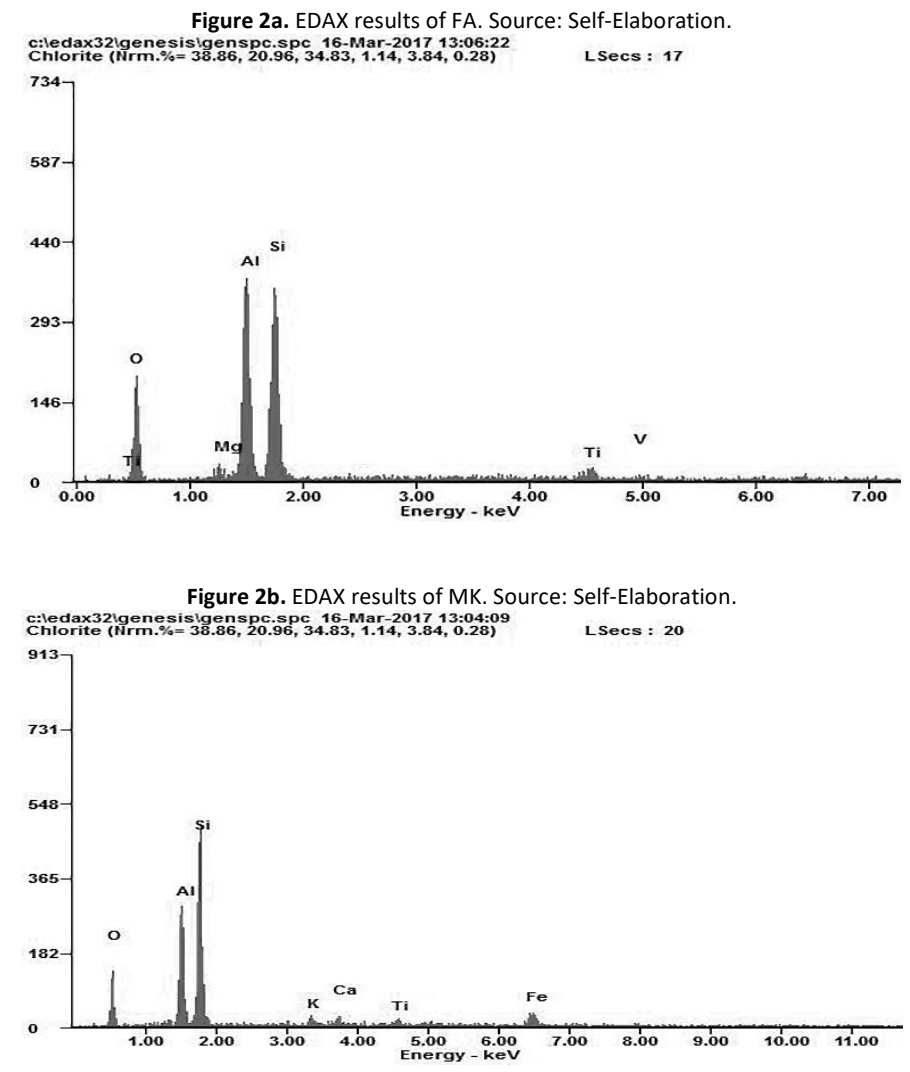

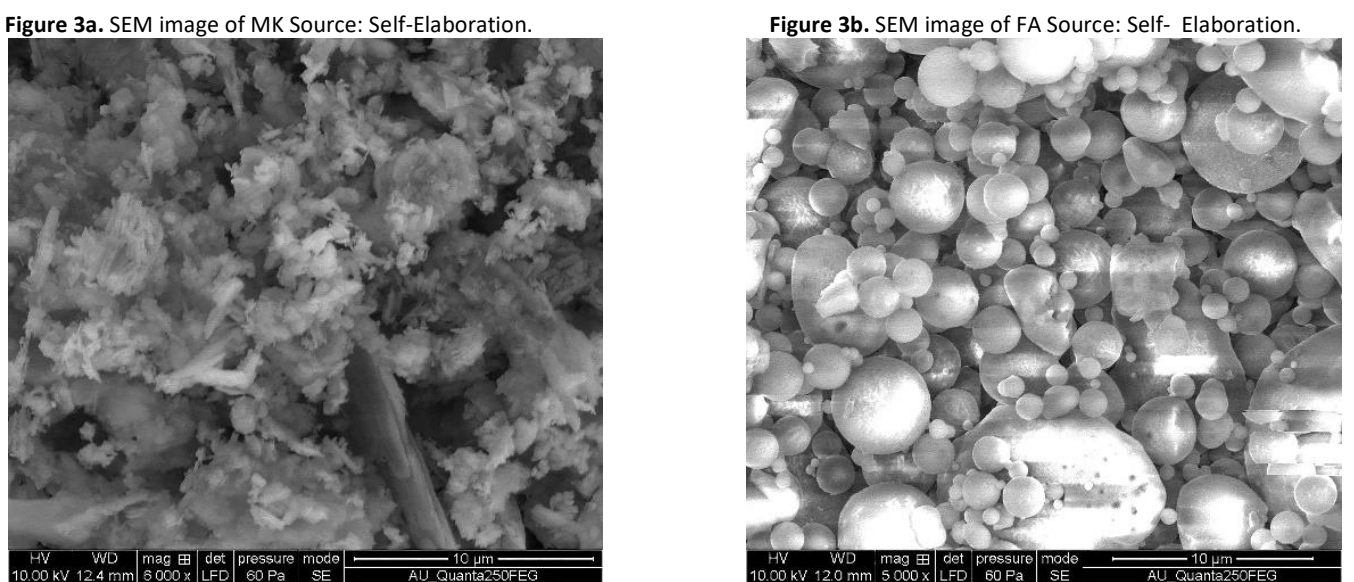

From SEM (Scanning Electron Microscope) images, it is evident that the shapes of MK particles are angular as shown in Figure $3 a$, and they are more irregular than FA particles which are spherical in nature as shown in Figure $3 b$, and hence FA improves the workability of SCC.

\section{Mix proportions}

Nine concrete mixes were made, the control mix had a total powder content of $575 \mathrm{~kg} / \mathrm{m}^{3}$ (Cement + FA + MK). Coarse aggregate content was maintained at $50 \%$ by volume of concrete $\left(778 \mathrm{~kg} / \mathrm{m}^{3}\right)$ and fine aggregate content was maintained at $50 \%$ by volume of mortar, the water powder ratio was kept as 1.05 by weight with air content being assumed to be $2.0 \%$. The mix proportion for various SCC mixes is given in Table 2.

The optimum dose of MK was arrived after several trials for optimizing the workability and compressive strength. For this FA was kept as constant as $30 \%$ by volume of total powder content and MK was varied at $5 \%, 10 \%$ and $15 \%$ by volume of total powder content. At fresh state, the workability tests were conducted to find out its filling ability, passing ability and segregation resistance. Then from each concrete, nine cubes ( $150 \mathrm{~mm}$ size), 12 cylinders $150 \mathrm{~mm}$ in diameter and $300 \mathrm{~mm}$ in height were cast to study their mechanical behavior. Then the optimum dose of FA and MK was fixed based on its workability performance and mechanical strength. Then sisal fiber was added with this optimum dose of FA and MK. Sisal fiber was varied at $0.1 \%, 0.2 \%, 0.3 \%, 0.4 \%$ and $0.5 \%$ by weight of total cementitious content. The fresh properties of sisal fiber reinforced self compacting concrete (SFRSCC) were studied for each variation and the results are given in Table 3. Then from each concrete, fifteen cubes (150 mm size), 15 cylinders $150 \mathrm{~mm}$ in diameter and $300 \mathrm{~mm}$ in height were cast to study their mechanical behavior.

\begin{tabular}{lccccccccc} 
Mix ID & $\begin{array}{l}\text { Cement } \\
\left(\mathrm{kg} / \mathrm{m}^{3}\right)\end{array}$ & $\mathrm{FA}\left(\mathrm{kg} / \mathrm{m}^{3}\right)$ & $\begin{array}{l}\mathrm{MK} \\
\left(\mathrm{kg} / \mathrm{m}^{3}\right)\end{array}$ & $\begin{array}{l}\text { Fine } \\
\text { Aggregat } \\
\mathrm{e}\left(\mathrm{kg} / \mathrm{m}^{3}\right)\end{array}$ & $\begin{array}{l}\text { Coarse } \\
\text { Aggregate } \\
\left(\mathrm{kg} / \mathrm{m}^{3}\right)\end{array}$ & $\begin{array}{l}\text { Sisal } \\
\text { fiber(\% of } \\
\text { binder) }\end{array}$ & $\begin{array}{l}\mathrm{w} / \mathrm{p} \\
\text { ratio }\end{array}$ & $\begin{array}{l}\text { Super } \\
\text { Plasticizer }(\% \\
\text { of binder) }\end{array}$ & $\begin{array}{l}\text { VMA \% of } \\
\text { binder }\end{array}$ \\
\hline SCC0 & 575 & - & - & 917 & 778 & - & 0.33 & 1.25 & - \\
SCC1 & 373.7 & 118.6 & 24 & 917 & 778 & - & 0.37 & 1.25 & - \\
SCC2 & 345 & 118.6 & 47.6 & 917 & 778 & - & 0.375 & 1.25 & - \\
SCC3 & 316.2 & 118.6 & 71.4 & 917 & 778 & - & 0.379 & 1.25 & - \\
SFRSCC1 & 345 & 118.6 & 47.6 & 917 & 778 & 0.1 & 0.375 & 1.5 & - \\
SFRSCC2 & 345 & 118.6 & 47.6 & 917 & 778 & 0.2 & 0.375 & 1.5 & 0.3 \\
SFRSCC3 & 345 & 118.6 & 47.6 & 917 & 778 & 0.3 & 0.375 & 1.5 & 0.3 \\
SFRSCC4 & 345 & 118.6 & 47.6 & 917 & 778 & 0.4 & 0.375 & 1.5 & 0.3 \\
SFRSCC5 & 345 & 118.6 & 47.6 & 917 & 778 & 0.5 & 0.375 & 1.5 & 0.3 \\
\hline
\end{tabular}

\section{Testing of specimens}

\section{Properties of fresh concrete}

For determining the self compactability properties like filling ability, passing ability and segregation resistance the following tests such as slump flow, T50 time, J-ring flow, V-funnel flow times, L-Box blocking ratio, U-Box difference in height were performed. In order to minimize the effect of workability loss on variability of test results, fresh concrete properties were examined within a period of 20 minutes after mixing (Karmegam, 2014). 
The slump flow test is used to determine the ability of concrete to distort under its own weight against the friction of the surface without extrinsic constraint present (Siddique, 2011). In slump flow test, the time taken by the concrete to attain $500 \mathrm{~mm}$ was noted and also the final diameter of concrete in two perpendicular directions were measured and the average of the two diameter was taken. In order to determine the resistance against segregation the flow time was counted 5 minutes after the funnel was filled (T5min). A visual inspection of flow of concrete also gives an indication of the degree of segregation. Slump flow of $650 \mathrm{~mm}$ to $800 \mathrm{~mm}$ is typically required for SCC(EFNARC,2002). The stability of SCC was evaluated through V-shaped funnel flow time test, J-ring test was also used to determine the passing ability of the concrete. J-ring was placed in conjunction with the Abram's cone, which was kept centrally inside the J-ring. After the concrete has flown out freely, the extent of blocking was measured. In V-funnel test, the time required for SCC for emptying the $\mathrm{V}$-funnel by virtue of its own weight was noted and also the flow time at T5min was noted. The L-box ratio characterizes the filling and passing ability of SCC. In the L-box test, the sliding gate was suddenly opened and the SCC was allowed to flow out into the horizontal section. After the flow was stopped, the height of concrete at the beginning and at the ends was measured and the blocking ratio was determined. Blocking ratio is the ratio between height of concrete at the end and height of concrete at the beginning. U-box test was used to determine the filling ability of SCC. In the U-box test, the sliding gate was raised vertically and the concrete was permitted to flow to the other section and the height of concrete in both the section was measured. The difference in height of concrete in two sections gives the filling height.

To find out the fresh properties of SCC, a separate batch was prepared for all mixes. For all the mix proportions, required quantity of materials was weighed. Cement, FA, MK were mixed in dry state and that of coarse aggregate and fine aggregate were mixed in a mixer to obtain homogeneous mix. After the addition of water, super plasticizer was finally added to the wet mix. The mixing duration for SCC should be longer than that of conventional concrete to achieve complete homogeneity because of the difference in raw material (Rahman, Rashid, Hossain, Adrita\& Hossain, 2011). The casting of specimens was carried out immediately without vibration after checking the fresh properties of SCC. The top surface of the specimens was scraped to remove excess material and achieve smooth finish. All the specimens were removed from moulds after $24 \mathrm{~h}$ and cured in water at $20^{\circ} \mathrm{C}$ till testing. The results of different fresh properties tested for various mix combinations are given in Table 3.

A total of four mixes that were employed to determine the optimum dose of MK while FA was kept as constant as $30 \%$ by volume of total powder content. The optimum dose of MK was fixed based on workability performance, compressive strength and split tensile strength.

\section{Strength properties}

As per Indian Standard Codal provisions (BIS: 516-1979), the Compressive strength and split tensile strength and Modulus of Elasticity were determined. Compressive strength was determined at ages of 7 days, 28 days and 56 days on cubic concrete specimens, which were tested at right angles to the position of casting so that the bearing faces were sufficiently planer and smooth as to require no capping. The specimens were loaded at a constant strain rate until failure. To determine the compressive strength nine cubic specimens of $150 \mathrm{~mm}$ size were cast for each concrete mixture. Split tensile strength was evaluated at the age of 28 days, on cylindrical specimens of $150 \mathrm{~mm}$ diameter and $300 \mathrm{~mm}$ height in size (BIS 5816-1970). The Modulus of Elasticity of all mixes was determined at 28 days by casting and testing the cylindrical specimens having $150 \mathrm{~mm}$ diameter and $300 \mathrm{~mm}$ height (BIS:5816-1970).Three cylindrical specimens were cast for each concrete mixture for compressive strength, split tensile strength and Modulus of elasticity. The mean values attained from the test results of three specimens for all tests are calculated.

For determining Flexural strength, beam specimens were cast using the mould of size $1700 \mathrm{~mm} \times 150 \mathrm{~mm} \times 100 \mathrm{~mm}$. All the specimens were tested after 28 days of curing. The load is applied through hydraulic jack and the deflections were measured using the LVDTs connected to the beam in the pure bending region. The load was applied to the specimen until failure occurred and the test setup was shown in Figure 4. The beams were reinforced with two numbers of $10 \mathrm{~mm}$ diameter bars at bottom and two numbers of $8 \mathrm{~mm}$ diameter bars at top and $6 \mathrm{~mm}$ diameter bars were used as stirrups. The spacing of stirrups were increased towards the flexure zone of the beam specimens. The details of beam with reinforcement is presented in Figure 5. The performance of the specimen in terms of crack formation, first crack load, failure mode, maximum deflection and the ultimate load were observed during testing. 


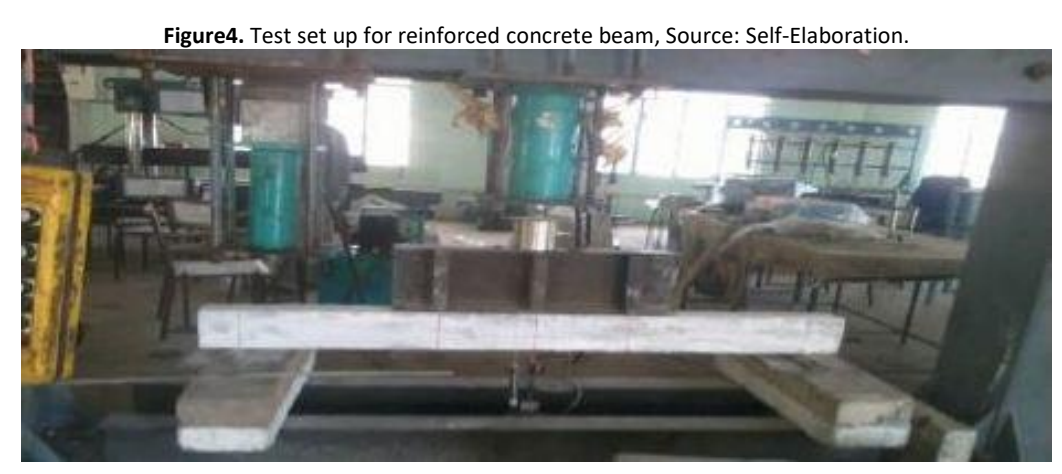

Figure 5. The details of beam with reinforcement, Source: Self-Elaboration.

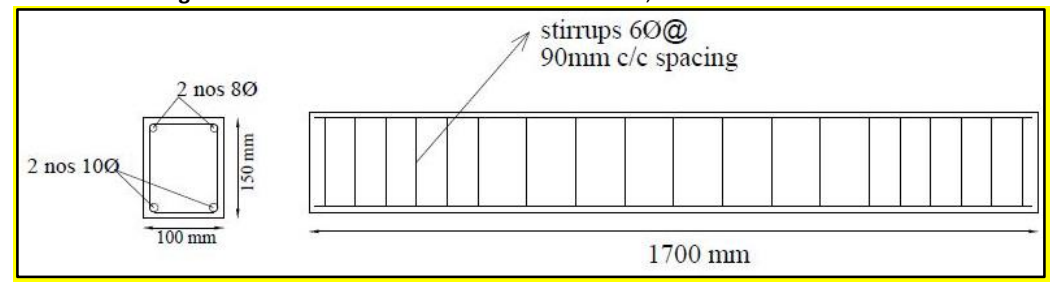

Results and Discussion

\section{Properties of fresh concrete}

The results of different fresh properties tested for various mix combinations are given in Table3. Slump flows of $650 \mathrm{~mm}$ to $800 \mathrm{~mm}$ are typically required for SCC and all mixes except SFRSCC containing $0.4 \%$ sisal fiber satisfied the requirement. The slump flow time for the concrete to reach the diameter of $50 \mathrm{~cm}$ for all the mixes were between 3 to 7seconds except SFRSCC5. J- Ring test denotes the passing ability of the SCC. All the mixes satisfy the EFNARC recommendations. To assess flowability and stability of SCC, V-funnel test was conducted. As per EFNARC guidelines, the time ranges between 6 to 12 seconds is sufficient to achieve self compactability. From this test results, it has been found that all the mixes except SFRSCC5, fulfilled the need of permissible flow time. L-box test assess the flow of concrete. To avoid blocking effect in the L-box, the maximum size of aggregate was taken as $12.5 \mathrm{~mm}$. The L-box ratio $\mathrm{h} 2 / \mathrm{h} 1$ for all the mixes was above 0.8 which satisfies the EFNARC standards. The filling ability of a SCC was assessed by conducting $\mathrm{U}$-box test. $\mathrm{U}$ box difference in height of concrete in two compartments was in the range of 0-20 mm except for the mix SFRSCC5. In this investigation when compared with control mix, the workability of SCC containing fly ash was increased but it was slightly decreased with the addition of MK. The addition of FA enhanced the rheological properties of SCC. It was realized that the addition fiber makes the SCC very harsh mix but it was overcome by adding viscosity modifying agent (VMA) with increased dose of Super plasticizer. However, the sisal fiber addition at $0.5 \%$ decreased the flow of concrete considerably due to formation of balling of fibers and also not satisfied the EFNARC guidelines and hence this dosage of fiber was not considered for further study. Concrete containing admixtures up to $45 \%$ replacement of cement exhibited in excellent workability and flowability. The details of the above are presented in Table 3.

\begin{tabular}{cccccccc}
\multicolumn{8}{c}{ Table 3. Fresh properties test results. Source: Self-Elaboration. } \\
\hline Mix ID & $\begin{array}{c}\text { Slump } \\
\text { flow(mm) }\end{array}$ & $\begin{array}{c}\text { T50cm } \\
\text { slump flow } \\
\text { (s) }\end{array}$ & $\begin{array}{c}\text { J Ring } \\
(\mathrm{mm})\end{array}$ & $\begin{array}{c}\text { V-funnel } \\
\text { flow (s) }\end{array}$ & $\begin{array}{c}\text { V-funnel } \\
\text { at T5min } \\
\text { (s) }\end{array}$ & $\begin{array}{c}\text { L-Box } \\
(\mathrm{mm})\end{array}$ & $\begin{array}{c}\text { U-Box } \\
(\mathrm{mm})\end{array}$ \\
\hline SCC0 & 655 & 7 & 9 & 11 & 12 & 0.9 & 20 \\
SCC1 & 675 & 5 & 8 & 9 & 11 & 0.93 & 10 \\
SCC2 & 685 & 3 & 8 & 8 & 10 & 1.0 & 15 \\
SCC3 & 700 & 5 & 10 & 9 & 12 & 1.0 & 18 \\
SFRSCC1 & 665 & 5 & 7 & 8 & 11 & 0.98 & 16 \\
SFRSCC2 & 655 & 5 & 8 & 8 & 11 & 0.97 & 18 \\
SFRSCC3 & 653 & 5 & 8 & 8 & 12 & 0.95 & 20 \\
SFRSCC4 & 650 & 7 & 9 & 9 & 12 & 0.93 & 20 \\
SFRSCC5 & 620 & 9 & 12 & 15 & 19 & 0.92 & 30 \\
\hline
\end{tabular}

Strength properties of hardened concrete 


\section{Compressive strength}

The mean, standard deviation and coefficient of variation of test results of compressive strength, split tensile strength and modulus of elasticity are shown in Table 4. The meager values of SD and CoV of test results can be associated to the intensified homogeneity of self compacting concrete mixes prepared. With increase in MK content from $5 \%$ to $15 \%$ with $30 \%$ FA, the compressive strength of SCC mixes developed between 26.48 and $24.37 \mathrm{MPa}$ at 7 days, 42.72 and $35.55 \mathrm{MPa}$ at 28 days \& 45.1 and $37.22 \mathrm{MPa}$ at 56 days, respectively. The compressive strength of SCC mixes at 7 days decreased due to the presence of FA and $\mathrm{MK}$, however the 56 days compressive strength increased to $8.62 \%$ for SCC2 and the compressive strength increased up to $15.78 \%$ for SFRSCC3 and this is due to delayed pozzolanic reaction. The compressive strength of SCC mixes increased with the addition of sisal fiber because propagation of micro cracks prevented (Yang, Joh \& Kim,2018) and it demands more energy for further propagation and hence the ultimate load was increased. The compressive strength of SFRSCC increased upto $0.4 \%$ of sisal fiber addition. However while compared with control mix the compressive strength of SFRSCC4 mix increased upto $5 \%$ and the compressive strength of SFRSCC3 increased upto $8 \%$ only and hence it could be concluded that the fibers has a minor influence on the compressive strength of SCC. The compressive strength test results of all mixes are given in Table4 and Figure 6 shows the effect of incorporating FA, MK and sisal fiber on compressive strength of concrete.

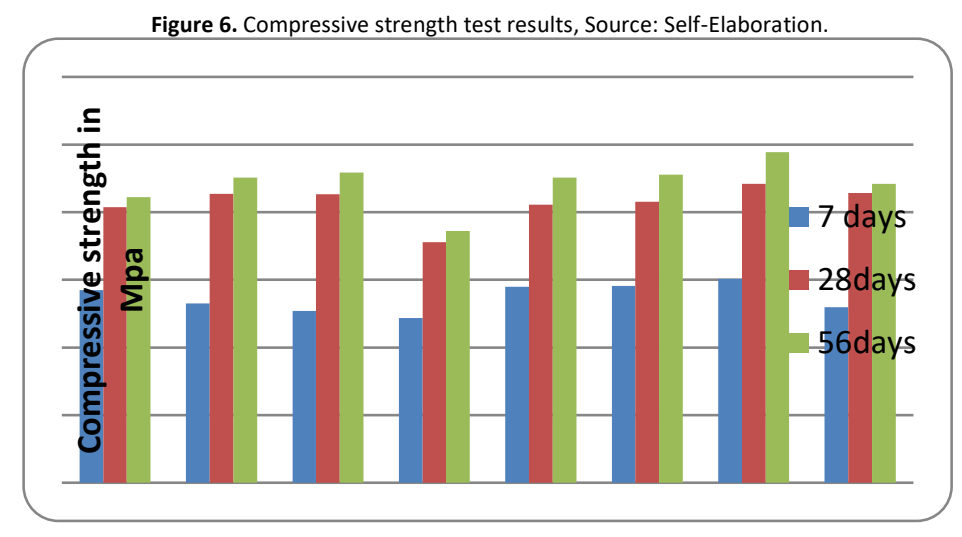

Table 4. Mean (M), standard deviation (SD) and Co efficient of variation (CoV in \%) of strength in hardened concrete. Source: Self -Elaboration.

\begin{tabular}{|c|c|c|c|c|c|c|c|c|c|c|}
\hline \multicolumn{2}{|c|}{$\begin{array}{c}\text { Properties of } \\
\text { hardened } \\
\text { concrete }\end{array}$} & & SCCO & SCC1 & $\mathrm{SCC} 2$ & SCC3 & SFRSCC1 & SFRSCC2 & SFRSCC3 & SFRSCC4 \\
\hline \multirow{9}{*}{ 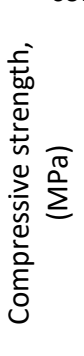 } & \multirow{3}{*}{$\begin{array}{l}\stackrel{n}{\frac{\pi}{0}} \\
\frac{\pi}{2} \\
8\end{array}$} & $M$ & 28.48 & 26.48 & 25.38 & 24.37 & 28.98 & 29.09 & 30.13 & 25.96 \\
\hline & & SD & 0.86 & 0.45 & 0.085 & 0.165 & 0.26 & 0.78 & 0.57 & 0.14 \\
\hline & & $\mathrm{CoV}$ & 3.02 & 1.70 & 0.33 & 0.68 & 0.90 & 2.68 & 1.89 & 0.54 \\
\hline & \multirow{3}{*}{$\stackrel{\infty}{\underset{N}{(})} \underset{\pi}{\frac{\pi}{0}}$} & $M$ & 40.72 & 42.72 & 42.66 & 35.55 & 41.11 & 41.57 & 44.19 & 42.86 \\
\hline & & SD & 0.745 & 0.710 & 0.856 & 0.960 & 0.945 & 1.125 & 0.450 & 0.875 \\
\hline & & CoV & 1.83 & 1.66 & 2.01 & 2.70 & 2.30 & 2.71 & 1.02 & 2.04 \\
\hline & \multirow{3}{*}{ 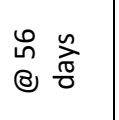 } & $\mathrm{M}$ & 42.2 & 45.1 & 45.84 & 37.22 & 45.09 & 45.54 & 48.86 & 44.17 \\
\hline & & $S D$ & 0.560 & 0.80 & 0.920 & 0.876 & 0.457 & 0.865 & 0.542 & 0.654 \\
\hline & & $\mathrm{CoV}$ & 1.33 & 1.77 & 2.01 & 2.35 & 1.01 & 1.90 & 1.11 & 1.48 \\
\hline \multirow{6}{*}{\multicolumn{2}{|c|}{ 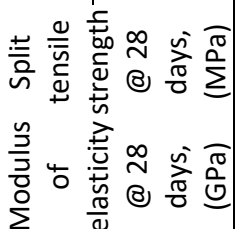 }} & $M$ & 3.64 & 3.52 & 3.40 & 2.617 & 3.67 & 3.74 & 3.96 & 3.53 \\
\hline & & SD & 0.045 & 0.067 & 0.04 & 0.065 & 0.120 & 0.024 & 0.046 & 0.135 \\
\hline & & $\mathrm{CoV}$ & 1.24 & 1.90 & 1.18 & 2.48 & 3.27 & 3.24 & 1.16 & 3.82 \\
\hline & & $M$ & 25.8 & 26.1 & 27 & 27.1 & 27.4 & 27.9 & 28.3 & 28.1 \\
\hline & & SD & 0.11 & 0.05 & 1.26 & 0.45 & 0.51 & 0.86 & 0.74 & 1.05 \\
\hline & & CoV & 0.28 & 0.12 & 3.10 & 1.08 & 0.82 & 1.32 & 1.01 & 1.36 \\
\hline
\end{tabular}

\section{Split tensile strength}

The test results of splitting tensile strength for all mixes are given in Table 4 .The splitting tensile strength of all mixes varies between 2.617 MPa and 3.96 MPa splitting tensile strength decreased with increase in the percentage of MK. SCC contains FA (30\%) and MK in the percentage of 5 and 10 exhibited decreased splitting tensile strength. The tensile strength of SCC mixes decreased due to the presence of fly ash (Siddique, 2011). SCC mix contains 30\% FA and 10\% MK decreases the tensile strength up to $7 \%$. The SFRSCC contains $0.3 \%$ of fibers content has given maximum increase in split tensile strength as $8.8 \%$ while compared with control mix. The split tensile strength of SCC2 was increased up to 
$17 \%$ by the addition of sisal fiber. It can be noticed that the addition of sisal fiber increases the tensile strength up to $8 \%$ and this may be attributed by bridging mechanism of fiber (Prakash, 2020).

\section{Modulus of Elasticity}

The test results on modulus of elasticity of all mixes are given in Table 4. It is evidenced that the modulus of elasticity of concrete was increased nominally from $25.8 \mathrm{GPa}$ to $28.3 \mathrm{GPa}$ and this can be achieved by the addition of fibers.

\section{Flexural strength}

The test results of flexural performance is given in Table 5 and plotted in Figure 7.

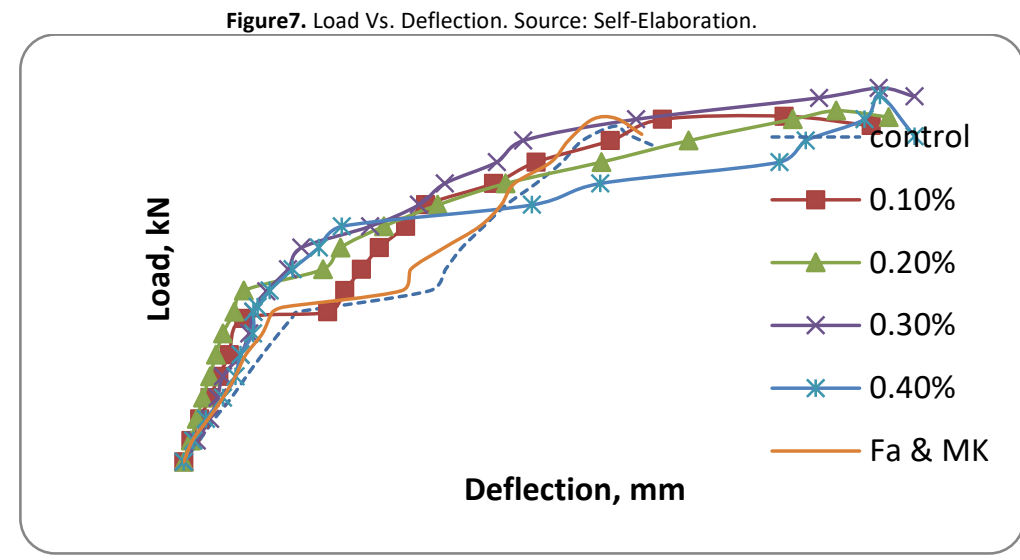

\begin{tabular}{lcccl}
\hline \multicolumn{5}{c}{ Table 5. Flexural strength test results. Source: Self-Elaboration. } \\
\hline Mix ID & $\begin{array}{l}\text { First crack } \\
\text { load }(\mathrm{kN})\end{array}$ & $\begin{array}{l}\text { Ultimate failure } \\
\text { load }(\mathrm{kN})\end{array}$ & $\begin{array}{l}\text { Maximum } \\
\text { at mid span }(\mathrm{mm})\end{array}$ & $\begin{array}{l}\text { Mode } \\
\text { failure }\end{array}$ \\
\hline $\begin{array}{l}\text { SCC0 } \\
\text { (0\% FA\&0\%MK) }\end{array}$ & 12.5 & 37 & 24.9 & By flexure \\
SCC2 & 15 & 40.5 & 28.6 & By flexure \\
30\%FA\&10\%MK & 16.75 & 40.4 & & \\
SFRSCC1 & 17.5 & 42 & 34.5 & By flexure \\
SFRSCC2 & 19.92 & 43.4 & 37.5 & By flexure \\
SFRSCC3 & 20 & 42.75 & 40 & By flexure \\
SFRSCC4 & & 41 & By flexure \\
\hline
\end{tabular}

Figure 7 shows that the results of load deflection behavior of RC beam with sisal fibers at different dosages and RC beams without fiber. From the figure, it is evidenced that the RC beams with fiber exhibit good flexural stiffness than normal RC beams. In fiber reinforced RC beam, the yield stage and failure stage are related to fiber factor. Here, Sisal fiber added RC beams undergone larger displacement before failure occurs (You, Chen \& Dong, 2011).

Flexural toughness is a measure of the energy absorption capacity of the concrete beam was measured from the area under the load deflection curve plotted using bending test results. The test results given in Table 6 show that the sisal fiber reinforced beam at the dosage of $0.3 \%$ attained much comparable flexural toughness value and was increased to $51 \%$ greater when compared to normal RC beam. However, the flexural toughness of SFRSCC4 was decreased when compared with SFRSCC3.

The crack pattern of tested specimens were shown in Figure 8. 


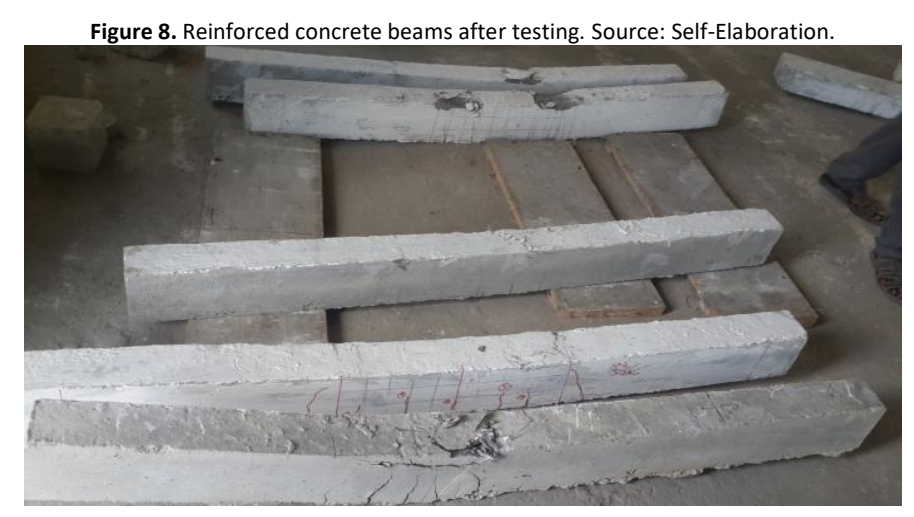

From Figure8, no horizontal cracks were witnessed. The cracks were formed in the flexure zone only. From the test results shown in Table.5, it has been observed that all the beams show a flexural performance. Based on failure as well as crack pattern, it has been evidenced that no possibility of bond failure. When compared with control specimens, the ultimate load carrying capacity of fiber reinforced specimens is increased and performed well and all the specimens proved that they are under reinforced. After the first crack formation, the reinforcement started to yield, a number of cracks had formed in the flexure zone and it proved that the specimens are more ductile because the addition of fiber. At the ultimate load the crushing of concrete takes place in compression zone. While compared with control specimens, more number of cracks was formed in the flexure zone of fiber reinforced specimens. The reduction in ultimate load of beam with $0.4 \%$ sisal fiber is witnessed however it performs better when compared with control specimens.

The ductility of a structural member is essential since it shows the capability to undergo huge displacement under described loading. During bending test, yield displacement and ultimate displacement were measured as shown in Table 6.

\begin{tabular}{|c|c|c|c|c|c|c|c|}
\hline Specimen ID & $\begin{array}{l}\text { Experimental } \\
\text { test result, } \mathrm{M}_{\mathrm{UT}} \text {, } \\
\mathrm{kNm}\end{array}$ & $\begin{array}{l}\text { Analytical } \\
\text { result, } \\
\text { MUA, kNm }\end{array}$ & $\begin{array}{l}\text { Ratio } \\
\text { MUT }_{\text {M }} \\
M_{U A}\end{array}$ & $\begin{array}{l}\text { Yield } \\
\text { displacemen } \\
\mathrm{t}, \mathrm{mm}\end{array}$ & $\begin{array}{l}\text { Ultimate } \\
\text { Displacement }\end{array}$ & $\begin{array}{l}\text { Ductility } \\
\text { Index }\end{array}$ & $\begin{array}{l}\text { Flexural } \\
\text { Toughness } \\
\text { kN-mm }\end{array}$ \\
\hline SCCO & 9.25 & 6.18 & 1.45 & 8.5 & 24.9 & 2.93 & 1019 \\
\hline SCC2 & 10.13 & 6.22 & 1.63 & 9 & 28.6 & 3.18 & 1208 \\
\hline SFRSCC1 & 10.09 & 6.19 & 1.63 & 9.25 & 34.5 & 3.73 & 1248 \\
\hline SFRSCC2 & 10.49 & 6.20 & 1.69 & 9.8 & 37.5 & 3.83 & 1411 \\
\hline SFRSCC3 & 10.85 & 6.25 & 1.74 & 9.5 & 40 & 4.21 & 1535 \\
\hline SFRSCC4 & 10.69 & 6.16 & 1.74 & 8 & 41 & 5.13 & 1529 \\
\hline
\end{tabular}

The displacement ductility is the ratio between ultimate displacement and yield displacement. The table 6 , indicates that the ductility index ranges between 3 to 5 and it also witnessed to be a measure of good ductility (Soutos\&Lampropoulos,2012).

Conclusions

The effects of addition of fly ash, meta kaolin and sisal fiber on mechanical properties such as compressive strength, split tensile strength of concrete and the flexural performance such as flexural toughness, ductility, load-deflection behavior of reinforced concrete beam were studied. The important conclusions drawn from this investigation are summarized as follows:

- From Scanning Electron Microscope images, it is found that the meta kaolin particles are angular and irregular in shape and hence affects the workability of concrete. But FA Particles are spherical in nature and hence improves the workability of self compacting concretemixes. The mix Self compacting concrete contains (fly ash $30 \%$ amd meta kaolin $10 \%)$ exhibits best results in terms of fresh concrete flow ability.

- Replacement of cement by mineral admixtures up to $45 \%$ (fly ash $30 \%$ and meta kaolin $10 \%$ ) was not affected the fresh state properties of self compacting concrete.

- The addition of sisal fiber into self compacting concrete demands higher dosage of superplasticizer and also demands the addition of viscosity modifying agent. In terms of fresh state behavior, all the mixes except self compacting concrete contains fly ash $30 \%$, meta kaolin $10 \%$ and sisal fiber $0.5 \%$, show better flow ability.

- The compressive strength of SCC mixes increased with the addition of sisal fiber because propagation of micro cracks prevented and it demands more energy for further propagation and hence the ultimate load is increased but it is nominal. The compressive strength of SFRSCC increased up to $0.4 \%$ of sisal fiber addition. 
- The sisal fiber reinforced self compacting concretecontains $0.3 \%$ of fibers content has given maximum increase in split tensile strength as $8.8 \%$ while compared with control mix. The split tensile strength of Self compacting concrete contains (fly ash $30 \%$ and meta kaolin 10\%) was increased up to $16.6 \%$ by the addition of sisal fiber. Thus the sisal fiber addition proved to be very effective in increasing strength of concrete.

- The flexural toughness of reinforced concrete beams with sisal fiber was greater than that of normal reinforced concrete beams and the presence of fibers make the concrete more ductile.

- Based on the above discussions, it is concluded that the best concrete mixture in terms of hardened concrete performance is the mix prepared with sisal fiber reinforced self compacting concrete contains sisal fiber $0.3 \%$, fly ash $30 \%$ and meta kaolin $10 \%$.

References

Bao, H. M., \& Li, S. (2010). Research on Mechanical Performance of Sisal Fiber Reinforced Concrete and its Mechanism. Advanced Materials Research,168-170, 925-930. doi:10.4028/www.scientific net/amr.168-170.925.

BIS:383(2016). Specification for coarse and fine aggregates, Bureau of Indian Standards, New Delhi, India.

BIS 516 -1959, Indian standard, Methods of tests for strength of concrete, Bureau of Indian Standards, New Delhi, India.

BIS 5816-1970, Method of test splitting tensile strength of concrete cylinders, Bureau of Indian Standards New Delhi, India.

BIS: 9103 - 1999, Specification for concrete admixture, Bureau of Indian Standards, New Delhi, India.

BIS 12269-2013, Ordinary Portland cement, Grade: 53, Bureau of Indian Standards, New Delhi, India.

Domone, P. (2007). A review of the hardened mechanical properties of self-compacting concrete. Cement and Concrete Composites, 29(1), 1-12. doi:10.1016/j.cemconcomp.2006.07.010.

EFNARC. (2002). Specification and guidelines for self-compacting concrete, UK.

Jin, X., \& Li, Z. (2003). Effects of Mineral Admixture on Properties of Young Concrete. Journal of Materials in Civil Engineering, 15(5), 435-442. doi:10.1061/(asce)0899-1561(2003)15:5(435).

Karmegam, A., Kalidass, A., \&Ulaganathan, D. (2014). Utilization of granite sawing waste in self compacting concrete. Journal of the Croatian Association of Civil Engineers, 66(11), 997-1006. doi:10.14256/jce.1117.2014.

Khatib, J. (2008). Performance of self-compacting concrete containing fly ash. Construction and Building Materials,22(9), $1963-1971$. doi:10.1016/j.conbuildmat.2007.07.011.

Köroğlu, M. A. (2019). Behavior of composite self-compacting concrete (SCC) reinforced with steel wires from waste tires. Revista de laConstrucción 17 (3), 284-498. https://doi.org/10.7764/RDLC.17.3.484

Okamura, H., Ozawa, K., \&Ouchi, M. (2000). Self-compacting concrete. Structural Concrete,1(1), 3-17. doi:10.1680/stco.2000.1.1.3.

Oyejobi, D., Raji, S., Aina, S., \&Siva, A. (2019). Physio-chemical and microstructural characteristics of selected pozzolanic materials for cement and concrete production. Nigerian Journal of Technological Development,16(3), 111. doi:10.4314/njtd.v16i3.4.

Prakash, R., Thenmozhi, R., Raman, S. N., \& Subramanian, C. (2020). Fibre reinforced concrete containing waste coconut shell aggregate, fly ash and polypropylene fibre. Revista Facultad de Ingeniería Universidad De Antioquia, 94, 33-42. doi:10.17533/10.17533/udea.redin.20190403.

Rahman, M.M., Rashid, M.H., Hossain, M.A.,Adrita F.S.\& Hossain, T. (2011). Mixing time effects on properties of self compacting concrete.ARPN Journal of EngineeringandApplied Sciences, 6 (8), 108-114.

Santha Kumar A. R. (2006). Concrete Technology, ISBN No. 0-19-567153-8, Oxford University Press, India.

Shetty M.S. (2008). Concrete Technology Theory and Practice, ISBN no. 978-81- 219-0003-4, S Chand and Company Pvt Ltd, New Delhi, India.

Siddique, R. (2011). Properties of self-compacting concrete containing class F fly ash. Materials \& Design, 32(3), $1501-1507$. doi:10.1016/j.matdes.2010.08.043.

Silva, F. D., Chawla, N., \&Filho, R. D. (2008). Tensile behavior of high performance natural (sisal) fibers. Composites Science and Technology, 68(1516), 3438-3443. doi:10.1016/j.compscitech.2008.10.001.

Soutsos, M., Le, T., \&Lampropoulos, A. (2012). Flexural performance of fibre reinforced concrete made with steel and synthetic fibres. Construction and Building Materials, 36, 704-710. doi:10.1016/j.conbuildmat.2012.06.042.

Uysal, M., \& Yilmaz, K. (2011). Effect of mineral admixtures on properties of self-compacting concrete. Cement and Concrete Composites, 33(7), 771776. doi:10.1016/j.cemconcomp.2011.04.005.

Uysal, M., Akyuncu, V., Tanyildizi, H., Sumer, M., \&Yildirim, H. (2019). Optimization of durability properties of concrete containing fly ash using Taguchi's approach and Anova analysis. Revista de la Construcción, 17(3), 364-382. doi:10.7764/rdlc.17.3.364.

Venkateshwaran, N., Elayaperumal, A., Alavudeen, A., \&Thiruchitrambalam, M. (2011). Mechanical and water absorption behaviour of banana/sisal reinforced hybrid composites. Materials \& Design ,32(7), 4017-4021. doi:10.1016/j.matdes.2011.03.002. 
Yang, I., Joh, C., \& Kim, K. (2018). A Comparative Experimental Study on the Flexural Behavior of High-Strength Fiber-Reinforced Concrete and HighStrength Concrete Beams. Advances in Materials Science and Engineering, 2018, 1-13. doi:10.1155/2018/7390798.

You, Z., Chen, X., \& Dong, S. (2011). Ductility and strength of hybrid fiber reinforced self-consolidating concrete beam with low reinforcement ratios. Systems Engineering Procedia, 1, 28-34. doi:10.1016/j.sepro.2011.08.006.

Zhao, X., Li, R. K., \& Bai, S. (2014). Mechanical properties of sisal fiber reinforced high density polyethylene composites: Effect of fiber content, interfacial compatibilization, and manufacturing process. Composites Part A: Applied Science and Manufacturing, 65, 169-174. doi:10.1016/j.compositesa.2014.06.017.

Zhang, C., Alam, Z., Sun, L., Su, Z., \&Samali, B. (2018). Fibre Bragg grating sensor-based damage response monitoring of an asymmetric reinforced concrete shear wall structure subjected to progressive seismic loads. Structural Control and Health Monitoring, 26(3). doi:10.1002/stc.2307. 